\title{
RADIKALISME PESANTREN: Studi terhadap Pesantren Darul Wahyain Magetan
}

\author{
Irsyadunnas \\ Universitas Islam Negeri Sunan Kalijaga Yogyakarta \\ irsyadsyamsir@gmail.com
}

Diterima 30 Maret 2018 | Direview 09 September 2018 | Diterbitkan 01 Oktober 2018

\begin{abstract}
Quoting BNPT's statement, there are at least 19 Islamic boarding school in Indonesia indicated to support the activities of radicalism and terrorism. Initially, the statement was based on several analytical factors, namely, the historical linkages of the postconflict pesantren establishment, as well as the association of the founding figures with some organizations that allegedly taught the radical flow. Starting from this statement, it is urgent to do research on one of the radically categorized pesantren, namely Pesantren Darul Wabyain Magetan. The reason for the selection of this pesantren according to information that the authors get from various sources, there are no signs or real evidence on the ground indicating that the Pesantren is based radically. The existence of Pondok Pesantren Darul Wabyain in Magetan does not meet the criteria to be called a radical pesantren, as formulated by the experts, namely textual, unilateral truth claims, a priori with western, anti-secular and extreme. In relation to the curriculum it can be explained that in general, the curriculum applied in Pesantren Darul Wabyain is not all that directs his santri into radicalist or terrorist.
\end{abstract}

Keywords: Radicalism, Terrorism, Pesantren, Santri.

\section{Abstrak}

Setidaknya terdapat 19 pesantren di Indonesia yang diduga oleh BNPT terindikasi mendukung kegiatan radikalisme dan terorisme. Indikasi dari pernyataan tersebut didasarkan pada beberapa faktor analisis, yakni: keterkaitan historis pendirian pesantren pasca konflik, serta keterkaitan para tokoh pendiri dengan beberapa organisasi yang diduga mengajarkan aliran radikal. Bertitik tolak dari pernyataan tersebut, urgen kiranya melakukan riset terbadap salah satu pesantren yang dikategorikan radikal, yakni Pesantren Darul Wabyain Magetan. Alasan pemiliban pesantren ini karena menurut informasi yang penulis dapatkan dari berbagai sumber, tidak ada tanda-tanda atau bukti-bukti real di lapangan yang mengindikasikan babwa pesantren tersebut berbasis radikal. Keberadaan Pondok Pesantren Darul Wabyain di Magetan tidak memenubi kriteria untuk disebut sebagai pesantren radikal, sebagaimana yang dirumuskan oleh para pakar, yakni tekstualis, klaim kebenaran sepibak, apriori dengan barat, anti sekuler, dan ekstrim. Terkait dengan kurikulumnya dapat dijelaskan bahwa secara umum, kurikulum yang diterapkan di Pesantren Darul Wabyain tidak ada sama sekali yang mengarabkan para santrinya menjadi seorang radikalis atau teroris.

Kata kunci: Radikalisme, Terorisme, Pesantren, Santri

\section{Pendahuluan}

Dibukanya kran demokrasi dengan gerakan reformasi besar-besaran tahun 1998, mengantarkan Indonesia memasuki babak baru, era keterbukaan. Era keterbukaan ini oleh R. William Liddle disebut sebagai fase liberalisasi politik yang ditandai dengan meruahnya aspirasi yang disampaikan secara publik setelah sekian dikungkung oleh otoritarianisme Orde Baru. ${ }^{1}$ Salah satu konsekuensinya adalah munculnya berbagai organisasi masyarakat (ormas), tak terkecuali ormas berbasis Islam dengan ragam gerakan dan ideologi yang diusungnya seperti kelompok Islam berhaluan 'garis keras' (radikal). Beberapa contoh kelompok Islam garis keras/radikal yang lahir pasca Orde Baru antara lain adalah Laskar Jihad, Front Pembela Islam (FPI), Hizbut Tahrir Indonesia, dan Majelis Mujahin Indonesia.

Di samping merebaknya radikalisme Islam, pasca lengsernya rezim Orde Baru ditandai pula dengan maraknya aksi terorisme di Indonesia. Tercatat, dalam rentang lebih dari satu dekade pasca reformasi, banyak kasus terorisme terjadi dibumi Indonesia sebut saja misalnya bom Bali, bom Hotel JW Marriot, bom Hotel Ritz Carlton, dana lannya.

Akibat ulah mereka pula, banyak kalangan yang menilai pesantren sebagai sarang teroris dan tempat persemaian benih-benih terorisme. Penilaian tersebut tentu saja tidak selamanya salah, namun juga tidak selamanya benar. Penilaian tersebut dapat dianggap benar

${ }^{1}$ Azyumardi Azra, et.al., Shari'a and Politics in Modern Indonesia (Singapore: ISEAS, 2003).

DOI: $10.18592 /$ ilmu ushuluddin.v\%vi\%i.2191 
karena ditemukannya fakta dan data yang menunjukkan adanya keterkaitan pesantren tertentu dengan terorisme serta keterlibatan sejumlah alumni pesantren dalam jaringan terorisme dan aksi radikalisme. Mengutip peryataan BNPT, setidaknya terdapat sejumlah 19 pesantren di Indonesia yang terindikasi mendukung kegiatan radikalisme dan terorisme. Secara awal pernyataan tersebut didasarkan pada beberapa faktor analisis, yakni: keterkaitan historis pendirian pesantren pasca konflik, serta keterkaitan para tokoh pendiri dengan beberapa organisasi yang diduga mengajarkan aliran radikal dan terlibat pada kerusuhan Ambon tahun 1999 - 2002. Pesantren-peseantren tersebut di antaranya adalah: (1) Pesantren Al-Mukmin Ngruki Surakarta, (2) Pesantren Darus Syifa' Lombok Timur, (3) Pesantren Darul Wahyain, Magetan, dan lainnya.

Keterkaitan pesantren dengan terorisme dan keterlibatan alumninya dalam berbagai aksi terorisme-radikalisme tentu saja merupakan fenomena yang memprihatinkan. Pesantren yang semestinya menjadi tempat untuk menuntut ilmu agama (tafaqquh fiddin) dan menanamkan doktrin Islam yang ramah, justru menjadi tempat yang subur bagi tumbuhkembangnya paham radikal. Kenyataan atas kondisi pesantren saat ini tentunya bertolak belakang dengan karakter otentik pesantren di masa-masa awal yang mampu menampilkan wajah toleran dan damai. Pesantren-pesantren di Jawa, terutama yang bermazhab Syafi'i, mampu bersikap akomodatif dengan budaya lokal, sehingga pembauran pesantren dengan masyarakat berlangsung dengan baik. Karena itu, hampir tidak pernah terjadi radikalisme di kalangan pesantren dalam bentuk aksi kekerasan, apalagi terorisme. ${ }^{2}$

Bertitik tolak dari realitas tersebut, urgen kiranya melakukan riset terhadap salah satu pesantren yang dikategorikan radikal, yakni Pesantren Darul Wahyain Magetan. Alasan pemilihan pesantren ini karena menurut informasi yang penulis dapatkan dari berbagai sumber, tidak ada tanda-tanda atau bukti-bukti real di lapangan yang mengindikasikan bahwa pesantren tersebut berbasis radikal. Karena itu penulis ingin mencari kebenaran dari informasi tersebut, yang dikaitkan dengan cap yang sudah dikeluarkan oleh BNPT. Beberapa hal yang akan dikaji adalah terkait dengan kriteria suatu pesantren dapat dikategorikan sebagai pesantren radikal, kurikulum Pesantren Darul Wahyain Magetan, dan mencari kebenaran alasan memasukan Pesantren Darul Wahyain Magetan dalam kategori pesantren radikal.

Melalui riset ini diharapkan dapat dimanfaatkan oleh para pemangku kepentingan (stakeholders), terutama pemerintah (seperti Kementerian Agama dan BNPT), untuk merumuskan kebijakan (policy) dan menyusun program-program deradikalisasi pesantren di Indonesia secara tepat dan efektif.

\section{Latar Belakang Berdirinya Pesantren Ma'had Aly Darul Wahyain ${ }^{3}$}

Pesantren Ma'had Aly Darul Wahyain merupakan lembaga pendidikan Islam tradisional tingkat tinggi. Pondok ini menempati area seluas $8000 \mathrm{~m}^{2}$, yang terletak di pinggir sawah, di Dukuh Ngrandu, Desa Sumberagung, Kecamatan Plaosan, Kabupaten Magetan, Jawa Timur. Lokasi di pinggir sawah ini pada masa lalu terdapat Pohon besar dan rindang yang diyakini sebagian masyarakat Sumberagung sebagai tempat yang angker, yang dihuni makhluk halus. Untuk mengusir makhluk halus tersebut masyarakat memberikan sesaji. Untuk menuju lokasi ini tidaklah sulit, karena pesantren berada tidak jauh dari jalan utama. Jika sudah berada di kota Magetan yang terletak di lereng Gunung Lawu ini, seseorang yang ingin pesantren bisa mencari angdes (angkutan Desa) jurusan Sumberagung yang biasa ngetem di Selatan Kota, di lingkungan pabrik kulit. Jalur angdes jurusan Sumberagung itu berakhir di perempatan pasar Desa Sumberagung. Dari tempat pasar Desa

\footnotetext{
${ }^{2}$ Ayub Mursalin dan Ibnu Katsir, "Pola Pendidikan Keagamaan Pesantren dan Radikalisme: Studi Kasus Pesantren-pesantren di Provinsi Jambi”, Kontekstualita, Vol. 25, No. 2, 2010, h. 257.

${ }^{3}$ Rangkuman hasil wawancara dengan Ustad Rosyid Ridlo, Ustad Hanif, dan Bapak Yusron, staf Kementerian Agama Kabupaten Magetan, pada 22 September 2017.
} 
Sumberagung lewati jalan besar ke arah Barat sejauh \pm 300 meter . Di sebelah kiri jalan yang menghubungkan Desa Sumberagung dengan Kec. Plaosan itu, akan terlihat bangunan sederhana yang nampak seperti perumahan perkampungan. Itulah komplek pesantren Ma'had Aly Darul Wahyain.

Hadirnya Pesantren Ma'had Darul Wahyain di Dukuh Ngrandu, Kecamatan Plaosan belumlah lama, yakni tahun 2009. Dari wawancara dengan pengasuh pondok Al Muslimun, dan juga tercatat dalam website bahwa pesantren ini merupakan pengembangan pendidikan Islam yang dikelola oleh Yayasan Al- Muslimun. Yayasan ini telah berdiri sejak tahun 1987 yang diprakarsai oleh Alm. K.H. Ngalimun (alumnus Pondok Pesantren Tebuireng Jombang), K.H. M. Buchory Burhanudin (alumnus Pondok Gontor Ponorogo) dan Alm. Kyai Kaderun (alumnus Pondok Pesantren Tebuireng). Pada awalnya Yayasan AlMuslimun lebih bergerak dalam bidang dakwah, melalui pengajian-pengajian agama untuk masyarakat umum yang berpusat di masjid. Di samping itu, kyai juga melayani undanganundangan ceramah dari berbagai kecamatan atau wilayah sekitar Kabupaten Magetan.

Mulai tahun 2001, Yayasan Al-Muslimun telah mendirikan unit pendidikan dalam bentuk pondok puteri dengan jenjang kulliyatul mualimat (KMA) dan Tahfidzul Qur'an Takhasus (TQT). Kuliyatul Mualimat (KMA) adalah unit pendidikan setara dengan SLTP dan SLTA yang mengajarkan berbagai bidang ilmu agama. Para santri puteri ini selain mendapat ijazah pesantren juga mendapat ijazah SLTP dan SLTA melalui program persamaan paket B dan C dari Kementerian Agama. Adapun unit tahfidzul Qur'an takhasus (TQT) dikhususkan bagi para santri yang ingin mengahafal Al-Quran 30 juz, di unit ini hanya sedikit pelajaran di luar ilmu ilmu Al-Qur'an. Dalam perkembangannya Yayasan Al Muslimun, tahun 2009 mendirikan Ma'had Aly Darul Wahyain.

Di antara faktor yang melatar belakangi berdirinya Ma'had Aly Darul Wahyain adalah adanya pandangan tentang meningkatnya jumlah lembaga-lembaga pendidikan Islam yang memerlukan ustadz yang menguasai Al Quran dan Hadist. Selain itu permintaan dai-dai atau ustadz di majlis taklim yang mumpuni dalam bidang $\mathrm{Al}$ Quran dan Hadis dari masyarakat di berbagai daerah di Indonesia juga dirasakan makin meningkat, seiring dengan perkembangan Islam yang semakin semarak diberbagai komunitas. Sementara itu para lulusan pesantren di tingkat KMI, KMA maupun Madrasah Aliyah dinilai masih banyak yang belum siap untuk diterjunkan sebagai guru maupun dai dalam masyarakat. Atas kesadaran itu, maka yayasan Al Muslimun memandang penting untuk membangun Ma'had Aly untuk memenuhi kekurangtan tenaga guru dan dai tersebut. Keinginan tersebut nampaknya dapat terealisasi, karena secara kebetulan Ustadz Rasyid Ridho memang memiliki keinginan kuat untuk membangun pesantren Ma'had Aly. Menurut KHM Bukhori, bahwa ustadz Rosyid Ridho telah berusaha untuk membangun pesantren di salah satu tempat di Jawa Barat, tetapi karena satu dan lain hal tidak dapat berjalan dengan lancar. Singkat kata, akhirnya KHM Bukhori sebagai pemilik Yasayasan dan Pesantren Al-Muslimun mempercayakan kepada. ustadz Rasyid Ridlo, LC, sebagai pengasuh Pondok Pesantren Darul Wahyain di dukuh Ngrandu Desa Sumberagung, yang letaknya agak jauh dari lokasi Pesantren Al Muslimun, pada bulan Syawal 1429 H. Ada tiga alasan utama kenapa Ustadz Rasyid Ridho dipercaya Yayasan Al Muslimun untuk mengembangkan Ma'had Aly.

Pertama, Ustadz Rasyid Ridho selain diketahui sedang meninginkan untuk mengembangkan atau menjadi pengasuh pesantren, ia juga dipandang memiliki pendidikan agama yang berkualitas memadai untuk memimpin pesantren: Ustadz ini dinilai memiliki track record yang baik, alumni SD Al-Islam Solo 1987, KMI Gontor Ponorogo 1992 , dan alumni Darul Hadist Al-Khairiyah, Mekkah Saudi Arabia tahun 2003.

Kedua, dari sudut paham dan pandangan serta wawasan keagamaan, Ustadz Rasyid Ridho dinilai selaras dengan paham, pandangan dan wawasan keagamaan pengurus Yayasan dan pesantren Al Muslimun. Ustadz Rasyid Ridho dan KHM Buchory sama-sama alumni pondok Modern Gontor, sehingga memiliki dasar pemahaman agama yang selaras. 
Ketiga, alasan yang bersifat relasi, hubungan pertemanan. Ustadz Rasyid Ridho adalah anak Abu Bakar Baasyir dan tiga orang anak KHM Buchory belajar di Pesantren Ngruki yang dipimpin Abu Bakar Baasyir. Salah satu anak KHM Bukhori sudah mengenal Ustadz Rasyid ketika sedang belajar di pesantren Ngruki tersebut. Selain itu KHM Bukhori juga pernah berteman dan seangkatan dengan Abu Bakar Baasyir, ketika keduanya samasama belajar di pondok modern Gontor.

Faktor alasan ketiga ini, yang memungkinkan Pesantren Ma'had Aly ini dapat dicurigai pihak luar memiliki potensi sebagai pesantren yang rentan menjadi pesantren yang berpaham keagamaan radikal, meskipun menurut analisa penelitian singkat penulis bahwa pesantren ini hingga saat ini masih murni sebagai tempat belajar agama Islam yang bersifat damai, yang rahmatan lil alamin. Dilihat dari aktivitas pengasuh, kurikulum, kegiatan santri dan relasi sosial keagamaan yang berkembang, tidak ada fenomena yang mengarah pada pesantren radikal.

Hingga penelitian ini dilakukan, pesantren Ma'had Ali Darul Wahyain masih di bawah naungan yayasan Al-Muslimun, pimpinan KHM Bukhori. Keberadaan Yayasan dan Pesantren Al-Muslimun telah diakui oleh Kementerian Agama setempat, melalui keikutsertaannya dalam wajar dikdas. Pada awal pembukaannya, jumlah santri angkatan I gelombang I seluruhnya tidak lebih dari 20 orang yang berasal dari berbagai pesantren, kemudian setelah berjalan pendidikan sekitar tujuh bulan dibukalah penerimaan santri gelombang II yang berjumlah sekitar 20 orang lagi. maka total mahasantri pada periode awal sejumlah 40 orang (putra dan putri). Saat penelitian ini dilakukan jumlah mahasantri sebanyak 55 orang, dan telah menamatkan satu angkatan. Hanya saja, khusus pada pesantren Ma'had Aly ini, belum terdaftar secara resmi pada Kementerian Agama Kabupaten Magetan. Menurut pengasuhnya, di samping para pengasuh pesantren Ma'had tidak paham dengan prosedur bagaimana proses mendaftarnya, pada level mana Ma'had Aly yang dikembangkan ini didaftarkan. Sebab kalau didaftarkan sebagai pendidikan Ma'had Aly yang distandarkan Kementerian Agama, kurikulum yang susun dalam Ma'had Aly pada pesantren ini mungkin belum memadai. Selama lebih dari enam tahun ini komunikasi antara pesantren Ma'had Aly ini dengan Kementerian Agama belum terbangun, alias belum terjadi komunikasi yang efektif. Nampaknya kedua belah pihak saling menunggu, tidak ada yang proaktif untuk menyelesaikan masalah pendaftaran kegiatan pendidikan yang sudah berlangsung sejak tahun 2009 ini.

\section{Karakteristik Radikalisme dalam Pemikiran dan Aksi}

Untuk mengidentifikasi suatu paham, kelompok, dan gerakan sebagai radikal atau tidak, diperlukan seperangkat karakteristik. Terkait hal ini, beberapa ahli mencoba merumuskan kriteria-kriteria atau atribut tertentu yang merupakan ciri-ciri radikalisme.

M. Syafii Anwar, sebagaimana dikutip oleh Syamsudin Haris, menjelaskan tentang empat karakteristik utama gerakan Islam radikal yang muncul di Indonesia pasca lengsernya Presiden Soeharto. Empat karakteristik tersebut adalah: 1) cenderung mempromosikan peradaban tekstual Islam, sehingga melahirkan sikap kaku, literal, dan tidak toleran terhadap pihak yang berbeda dengan mereka, 2) setia kepada syariab minded, sehingga cenderung memperjuangkan formalisasi syariat Islam, baik pada tingkat negara maupun tingkat kehidupan masyarakat. Akibat formalisasi, maka simbol-simbol keislaman menjadi lebih utama ketimbang substansinya. 3) memiliki kepercayaan berlebihan terhadap teori konspirasi, yakni bahwa kemunduran dan keterbelakangan Islam merupakan konspirasi Barat, terutama Amerika dan sekutu-sekutunya. Islam hampir-hampir selalu dipandang sebagai korban dari konspirasi kekuatan Yahudi-Kristiani yang dipimpin AS. 4) cenderung 
mengembangkan agenda anti-pluralisme. Ide pluralism dalam bentuk apa pun cenderung dipandang sebagai ancaman bagi kebenaran tunggal yang dimiliki oleh Islam. ${ }^{4}$

Dengan meramu pendapat dari Mun'im A. Sirry, Dekmejian, Yusril Ihza Mahendra, dan Muhammad Wahyuni Nafis, Edi Susanto membuat karakteristik radikalisme agama yang meliputi enam hal, yaitu: 1) cenderung menafsirkan teks-teks kitab suci secara rigid atau kaku dan literalis atau tekstual; 2) cenderung memonopoli kebenaran atas tafsir kitab suci/agama, dan bahkan menganggap dirinya sebagai pemegang otoritas dalam penafsiran agama yang paling absah, sehingga menganggap penafsir kitab orang atau kelompok lain yang tidak sealiran adalah sesat dan halal untuk dimusuhi. 3) memiliki pandangan yang apriori terhadap ideologi dan budaya barat. Dalam kaitan ini dunia barat dipandang sebagai musuh bebuyutan, imperialis yang selalu mengancam akidah dan eksistensi umat Islam; 4) menyatakan perang terhadap paham dan tindakan sekular; dan 5) cenderung dan tidak segan-segan menggunakan cara-cara kekerasan dalam memperjuangkan nilai-nilai yang diyakininya, khususnya dalam berhadapan dengan modernitas dan sekularitas yang dinilainya menyimpang dan merusak keimanan. ${ }^{5}$

Menurut M. Zaki Mubarak, setidaknya ada beberapa karakteristik dari kelompok radikal, terutama yang ia maksud adalah kelompok Salafi, yaitu: sifatnya cenderung defensif (bertahan pada pendapatnya) saat berdialog/berdebat; defensif atas perubahan-perubahan yang ada hubungannya dengan masalah sosial sekalipun; absolutis dalam memahami konsepsi kebenaran; cenderung literal dalam memahami kitab suci (teks); eksklusif dalam memandang realitas sosial dan tidak percaya pada perubahan sosial (social enginering) dari luar agama Islam; realitas penuh dekadensi dan immoralitas terutama dihubungkan dengan religiusitas sehingga harus ditolak keberadaannya. Oleh sebab itu harus dilakukan perubahan kembali ke arah zaman kemenangan Islam (kemurnian Islam atau purifikasi) yang tidak diarahkan oleh perubahan realitas sosial. ${ }^{6}$ Dengan kata lain, purifikasi atau puritanisme sebetulnya menjadi ideologi paling inti dalam radikalisme. Khaled Abou el Fadl, dalam bukunya The Great Theft, sebagaimana dikutip oleh Zuly Qodir, menyatakan bahwa puritanisme adalah orientasi teologis, bukan mazhab pemikiran yang terstruktur dengan rapi. Oleh sebab itu, orang akan dapat menemukan varian-varian di dalamnya. Tetapi, yang tidak bisa hilang dari puritanisme adalah ideologi supremasi, bahwa mereka selalu merasa lebih unggul dan superior, yang berfungsi sebagai kompensasi atas perasaan kalah, tak berdaya, dan keterasingan, disertai sikap arogansi diri yang di dalamnya terkandung perasaan selalu benar ketika berhadapan dengan yang lain. Sekalipun "yang lain" itu juga tidak mudah diklasifikasikan apakah barat, kaum Ateis, sesama Muslim, pelaku bid'ah atau bahkan kaum perempuan. ${ }^{7}$ Dengan demikian, kelompok radikal yang umumnya memiliki ideologi puritan cenderung otoriter atau merasa paling benar, terlepas perasaan paling benar itu diekspresikan atau tidak.

Sedangkan menurut Zainal Abidin, Rektor IAIN Palu, radikalisme dicirikan dengan kecenderungan mereka yang: 1) Bersikap tertutup dan tidak suka dengan dialog terbuka untuk membahas pahamnya, 2) penyebaran pahamnya ditujukan kepada orang yang minim pengetahuan agamanya, terutama kalangan generasi muda yang selain minim juga masih

\footnotetext{
${ }^{4}$ Syamsudin Haris, Masalah-Masalah Demokrasi dan Kebangsaan Era Reformasi, Jakarta: Yayasan Obor Indonesia, 2014, h. 170

${ }^{5}$ Edi Susanto, ibid., h. 4. Karakteristik tersebut disarikan dari beberapa referensi yaitu: Mun'im A. Sirry, Membendung Militansi Agama: Iman dan Politik dalam Masyarakat Modern (Jakarta: Erlangga, 2003), h. 2-9; Dekmejian, Islam and Revolution, h. 4-8; Yusril Ihza Mahendra, "Fundamentalisme, Faktor dan Masa Depannya", dalam Muhammad Wahyuni Nafis, ed. Rekonstruksi dan Renungan Religius Islam (Jakarta: Paramadina, 1996), h.100-108.

${ }^{6}$ M. Zaki Mubarak, Genealogi Islam Radikal di Indonesia: Gerakan, Pemikiran dan Prospek Demokrasi (Jakarta: LP3ES, 2007), h. 29.

7Zuly Qodir, "Gerakan Salafi Radikal dalam Konteks Islam Indonesia”, ISLAMICA, Vol. 3, No. 1, September 2008, h. 11.
} 
labil. ${ }^{8}$ Syahrin Harahap, Guru Besar UIN Sumatera Utara, menambahkan bahwa ciri-ciri paham radikalisme adalah (pandangannya) sempit, fundamental, eksklusif, keras, dan selalu ingin mengoreksi paham orang lain.' Sedangkan menurut Kasubdit Napi Deradikalisasi BNPT, Kolonel Sigit Karyadi, orang yang terjangkiti paham radikal bersifat pilih-pilih dalam bersosialisasi, baik di dunia nyata maupun di media sosial. ${ }^{10}$

Radikalisme sering dikaitkan dengan Salafisme. Salafi berarti pengikut para al-salaf alsalih, yaitu tiga generasi pertama dalam sejarah Islam. Tokoh gerakannya dimulai dari Muhammad ibn 'Abd al-Wahhab sehingga juga dikenal sebagai Wahabi atau Salafi-Wahabi. Tokoh generasi berikutnya adalah Ibn Taymiyya dan Ahmad ibn Hanbal. Sedangkan tokoh kontemporer Salafi adalah para penulis produktif seperti Abdul Aziz Abdullah ibn Baz dan Muhammad Nasir al-Din al-Albani. Salafi menyebar luas di Indonesia terutama atas peranan para alumni dari universitas di Saudi Arabia dan Yaman, serta didukung oleh alumni LIPIA Jakarta. Adapun pesantren salafi di Indonesia melalui merebak sejak akhir 1980an. ${ }^{11}$

Salafi di Indonesia dibagi dalam 3 kategori: ${ }^{12}$ yang pertama salafi puritan: konsentrasi pada dakwah dan pendidikan, menggunakan cara-cara yang damai, relatif taat pada pemerintah. Kategori ini masih dibagi tiga lagi, yaitu: a) Rejectionist. eksklusif, menolak kerjasama dengan kelompok lain (hizbi), termasuk menolak kurikulum nasional. b) Cooperationist: lebih terbuka, mau bekerja sama dengan kelompok lain bahkan dengan pemerintah, c) Tanzimi: lebih tertata secara organisasi, ada tingkatan jabatan, dan tingkatan pusat dengan cabang. Contoh: Wahdah Islamiyah di Makassar, Sulawesi Selatan dan Harakah Sunniyah untuk Masyarakat Islami (HASMI) di Bogor, Jawa Barat.

Kedua, salafi haraki yang bersifat gerakan politik yang menolak tunduk terhadap pemerintah. Memposisikan Islam sebagai sistem yang paling lengkap dari Tuhan dan wajib ditaati oleh pemerintahan buatan manusia. Namun, kritiknya hanya bersifat verbal, tanpa kekerasan. Contoh: Al Mukmin Ngruki.

Terakhir yang dikenal dengan salafi jihadis yang lebih bercorak gerakan berkekerasan. Kelompok yang disebut terakhir ini meyakini bahwa keyakinan terhadap Islam harus kokoh. Perjuangan untuk menegakkan Islam tersebut harus dilakukan dengan kekuatan dan kekuasaan atau bahkan dengan kekerasan. Gerakan inilah yang mereka sebut dengan jihad fi sabilillah.

\section{Kelompok-kelompok Islam Radikal}

Suatu lembaga dapat dikatakan radikal atau tidak, selain ditinjau dari pemikiran yang mereka anut dan aktifitas yang mereka lakukan, juga dapat dilihat dari ada tidaknya relasi dengan kelompok lain yang dikenal sebagai kelompok radikal. Relasi tersebut dapat berupa sekedar jejaring kemitraan atau relasi bersifat sel, misalnya antara induk dengan cabang, atau cabang dengan ranting. Jikapun telah ditemukan adanya relasi, masih perlu lagi untuk dipastikan bagaimana hubungan antara suatu kelompok kepada kelompok radikal, apakah benar-benar sejalan atau mulai ada kerenggangan atau justru mulai berseberangan. Namun sebelum itu, perlu diketahui terlebih dahulu kelompok mana saja yang telah terindentifikasi sebagai kelompok radikal.

Menurut Arsyad Mbai, di Indonesia terdapat 16 kelompok Islam radikal yang bahkan sudah menyatakan bai'at atau ketaatan pada pimpinan ISIS, Al-Baghdadi, sedangkan 3 kelompok hanya sebatas simpatisan ISIS. Adapun 16 kelompok tersebut adalah: 1).

${ }^{8}$ Ini Dia Ciri-ciri Islam Radikal, Masyarakat Harus Tahu!http://islaminesia.com/2015/11

${ }^{9}$ Guru Besar UIN: Ciri Radikalisme, Gemar Koreksi Keyakinan Orang Lain, http://www.nu.or.id/post/read/71794

${ }^{10} \mathrm{https}$ // kumparan.com/nur-khafifah/ciri-ciri-orang-terjangkit-paham-radikal-menurut-bnpt\# C7DuMlsrtju5M631.99

${ }^{11}$ Din Wahid, "Nurturing Salafi manhaj: A study of Salafi pesantren in contemporary Indonesia", Wacana, Vol. 15 No. 2 (2014)., h. 368

${ }^{12}$ Din Wahid, Ibid. h. 372-373 
Mujahideen Indonesia Barat, 2) Mujahideen Indonesia Timur, 3) Jamaah Tawhid Wal JihadQ, 4) Forum Aktivis Syariah Islam, 5) Pendukung dan Pembela Daulah, 6) Gerakan Reformasi Islam, 7) Asybal Tawhid Indonesia, 8) Kongres Umat Islam Bekasi, 9) Umat Islam Nusantara, 10) Ikhwan Muwahid Indunisy Fie, 11) Jazirah Al-Muluk Ambon, 12) Ansharul Kilafah Jawa Timur, 13) Gerakan Tawhid Lamongan, 14) Khilafatul Muslimin, 15) Laskar Jundullah, 16) DKM Masjid Al Fataa. Sedangkan yang termasuk simpatisan ISIS adalah: 1) RING Banten, 2) Jamaah Ansharut Tauhid, dan 3) Halawi Makmun Group. ${ }^{13}$

Jamhari dan Jajang Jahroni, menyebut beberapa organisasi keagamaan yang berorientasi politis, yang oleh pengutipnya, Edi Susanto, disebut sebagai organisasi yang meramaikan wacana Islam radikal di Indonesia; yaitu: Hizbut Tahrir Indonesia (HTI), Front Pembela Islam (FPI), Komite Persiapan Penegakan Islam (KPPSI), Lasykar Jihad, Jamaah Islam Ahlussunah Waljamaah, Forum Ulama Ummat Islam Indonesia dan Majelis Mujahidin Indonesia (MMI). ${ }^{14}$

\section{Kurikulum dan Metode Pembelajaran Pesantren Darul Wahyain}

Sesuai dengan namanya, Ma'had Aly Pesantren Darul Wahyain menekankan pada penguasaan al-Qur'an dan Hadis. ${ }^{15}$ Kurikulum yang diterapkan di Pesantren Darul Wahyain adalah mengadopsi kurikulum dari Universitas Darul Hadis Al-Khairiyah, Mekkah, yang dikombinasikan dengan kurikulum Pesantren Modern Gontor. Hal ini karena Ustadz Rasyid Ridlo Ba'asyir, pengasuh Pesantren Darul Wahyain, memang alumni Universitas Darul Hadis Al-Khairiyah, Mekkah, dan Pesantren Modern Gontor. ${ }^{16}$

Secara umum, kurikulum yang diterapkan di Pesantren Darul Wahyain dibedakan berdasarkan program/level. Ada 3 (tiga) level/program yang terdapat di pesantren yaitu: program 'idadiyah, ta'biliyah, dan ta'miliyah. ${ }^{17}$ Untuk program 'idadiyah, materi yang diajarkan adalah adab (akhlak/etika), tajwid, dan bahasa Arab. Untuk program ta'biliyah, materi yang diajarkan adalah tafsir, hadis, akidah, fikih, dan sirah. Untuk program takmiliyah, materi yang diajarkan adalah fiqh dakwah, tsaqofatus sunah, dan firoq wal-afkar.

Pesantren Darul Wahyain menggunakan mulazamah sebagai metode utama dalam sistem pembelajarannya. Menurut Ustad Rasyid Ridlo Ba'asyir, Darul Wahyain menggunakan sistem pendidikan klasikal atau dikenal dengan istilah mulazamah dan dikombinasikan dengan sistem pendidikan pesantren dan ma'had modern. Tujuan mengkombinasikan dua sistem tersebut adalah upaya untuk mencapai kesempurnaan pendidikan peserta didik yang ada di Pesantren Darul Wahyain. ${ }^{18}$ Mulazamah adalah mengkaji suatu kitab dari awal hingga akhir. Sebelum menguasai bab awal, maka tidak diperkenankan mempelajari bab-bab selanjutnya. ${ }^{19}$

Mulazamah merupakan sistem pembelajaran yang alami dan telah digunakan oleh para ulama dari generasi ke generasi, terutama di wilayah timur tengah, khususnya Arab Saudi. Menurut pengelola Pesantren Darul Wahyain, mulazamah merupakan metode yang paling efektif dalam pembelajaran ilmu syariah, hingga menghasilkan para ulama yang sangat

${ }^{13}$ Berdasarkan keterangan Arsyaad Mbai di https://www.merdeka.com/peristiwa/ini-16-kelompokradikal-indonesia-yang-dibaiat-pemimpin-isis.html diakses 11 Oktober 2017

${ }^{14}$ Edi Susanto, "Kemungkinan Munculnya Paham Islam Radikal di Pondok Pesantren", Tadrîs. 2 Volume 2. Nomor 1. 2007, h. 1. Lihat pula dalam Jamhari dan Jajang Jahroni, Gerakan Salafi Radikal di Indonesia (Jakarta: PPIM, 2004).

${ }^{15}$ Wawancara dengan Ustad Rasyid Ridlo Ba'asyir, pada 21 September 2017. Pernyataan ini juga dibenarkan, misalnya oleh Ustadz Hanif dan Ustadzah Iffa, ustadz dan ustadzah Pesantren Darul Wahyain.

${ }^{16}$ Wawancara dengan ustadzah Iffa, pada 22 September 2017.

${ }^{17}$ Wawancara dengan Ustadz Hanif, pada 21 September 2017. Deskripsi tentang seluruh program Pesantren Darul Wahyain diambil dari dokumen tertulis Pesantren Darul wahyain (tidak dipublikasikan).

${ }^{18}$ Pejelasan tentang metode mulazamah juga dapat dilihat dalam video Profil Pesantren Darul Wahyain di kanal https://www.youtube.com/watch?v=_9urI6Kz4WI. Diakses pada 1 November 2017.

${ }^{19}$ Wawancara dengan Lukman, pada 22 September 2017. 
berkompeten. Beberapa ulama kontemporer yang pernah menjalani metode mulazamah antara lain Syaikh Muhammad Nashiruddin Albani, Syaih Abdul Aziz bin Abdullah bin Baz, Syaikh Muhammad bin Shalih Utsaimin, dan beberapa ulama lain yang dikenal sangat menguasai bidang ilmu syariah, sehingga menjadi rujukan kaum Muslim. ${ }^{20}$

Ustad Rasyid Ridlo Ba'asyir sendiri merupakan alumni Arab Saudi. Sangat mungkin ia menerapkan metode muzalamah di Pesantren Darul Wahyain karena terinspirasi saat belajar di sana. Pesantren Darul Wahyain memilih untuk menggunakan mulazamah sebagai metode dalam mendidik para santrinya dengan tujuan agar mereka mampu mencapai hasil yang maksimal dalam hal kaderisasi calon ulama. Pesantren Darul Wahyain menganggap bahwa mulazamah merupakan metode paling tepat dan efektif dalam pembelajaran ilmu syariah. Di antara kelebihan mulazamah dibandingkan sistem lainnya dalam pembelajaran ilmu syariah adalah karena dalam metode mulazamah setiap disiplin ilmu dipelajari secara tuntas dan terperinci, sebelum beralih ke disiplin ilmu yang lain. Dengan demikian, perhatian para santri dapat fokus untuk menguasai setiap disiplin ilmu syariah yang dipelajarinya secara mendalam, luas, dan tuntas. ${ }^{21}$

Selain beberapa pertimbangan di atas, berikut ini beberapa alasan mengapa Pesantren Darul Wahyain menggunakan metode mulazamah: ${ }^{22}$

1. Mulazamah adalah metode pembelajaran yang digunakan mayoritas salafus shalib dalam menuntut ilmu syariah, hingga menghasilkan suatu generasi ilmu yang mencengangkan dunia.

2. Mulazamah adalah metode pembelajaran yang lebih menekankan aspek penguasaan materi ilmu syariah secara rinci dan mendalam.

3. Mulazamah adalah metode pembelajaran yang terbukti lebih mampu melahirkan kader ulama yang memiliki kompetensi dan konsistensi dalam agama.

4. Mulazamah adalah metode pembelajaran yang menuntut para guru dan pelajar untuk fokus terhadap materi-materi ilmu syar'i yang diajarkan, kecuali bila terdapat hal lain yang dapat menjadi sarana penunjang; maka dipelajari sesuai kebutuhan.

5. Mulazamah memprioritaskan kualitas ilmu dan amal menurut neraca syariah. Oleh karena itu, berbagai hal yang menjadi kendala harus ditinggalkan, baik personal maupun materi atau kegiatan lainnya.

6. Diharapkan metode mulazamah ini akan menghasilkan sosok calon ulama yang mampu mengarahkan masyarakat dan mencukupi kebutuhan masyarakat terhadap ilmu agama.

7. Diharapkan pula pasca mengikuti mulazamah, para alumnus siap mengikuti program kaderisasi ulama, baik dalam maupun luar negeri.

\title{
F. Karakteristik Radikalisme dan Pesntren Darul Wahyain.
}

Radikalisme merupakan suatu faham atau aliran yang menginginkan perubahan atau pembaharuan sosial dan politik dengan cara kekerasan atau drastis; bahkan juga diartikan sebagai sikap ekstrem dalam aliran politik. ${ }^{23}$ Karena definisi seperti inilah maka istilah radikal sering dilawankan dengan istilah moderat. Moderat digambarkan sebagai suatu sikap mengambil jalan tengah ketika menghadapi konflik dengan gagasan atau ide lain, dengan kata lain cenderung kompromistis atau kooperatif. Sebaliknya, radikal berarti secara konsisten mempertahankan ide secara utuh ketika dihadapkan pada konflik dengan ide lain, atau dengan kata lain non-kooperatif.

Dengan mempertimbangkan definisi ini secara umum Pesantren Darul Wahyain tidak sepenuhnya sesuai. Meskipun melalui gerakan pendidikan dan dakwahnya, mereka mencitacitakan sebuah kehidupan sosial keagamaan yang ideal sebagimana yang terjadi pada zaman

\author{
${ }^{20}$ Ibid. \\ ${ }^{21}$ Ibid. \\ ${ }^{22}$ Ibid. \\ ${ }^{23}$ https://kbbi.web.id/radikalisme
}


ulama salaf. Namun mereka menempuh cara damai dan evolutif tidak sebagaimana perubahan yang dilakukan oleh gerakan radikal.

Apabila Bilveer Singh dan Abdul Munir Mulkhan mengartikan radikalisme sebagai paham atau aliran yang menginginkan perubahan atau pembaruan sosial dan politik secara drastis bahkan seringkali ditempuh dengan cara-cara kekerasan. ${ }^{24}$ Dimana sebagai konsekuensinya orang yang radikal akan bersikap dan bertindak untuk melakukan perubahan sosial politik dengan cara yang mengarah atau berupa kekerasan. Maka ketika radikalisme bersentuhan dengan agama atau termasuk ajaran agama Islam, maka maknanya menjadi sikap dan tindakan yang keras untuk mengubah kondisi sosial politik dengan menggunakan dalih ajaran agama sebagai pembenarnya.

Dalam konteks pesantren Darul Wahyain gambaran seperti ini tidaklah terlihat, karena jalur pendidikan dan dakwah yang mereka pilih sama sekali tidak terlihat secara langsung melakukan tindakan perubahan kondisi sosial politik dengan secara drastis, revolusioner apalagi kekerasan. Baik dalam pendidikan yang dilakukan di pesantren maupun dalam dakwah mereka khususnya pada masyarakat sekitar pesantren tidak memuat unsur-unsur politik apalagi provokasi untuk memberontak atau makar terhadap pemerintah.

Ilmu sosial sering menggambarkan istilah radikalisme memiliki karakteristik yang dapat dikaitkan dengan sikap ketidakpuasan seseorang atau kelompok terhadap keberadaan status quo dan tuntutan terhadap sesuatu yang telah mapan untuk melakukan perubahan secara mendasar terhadap persoalan tertentu, dimana dahulu sering dikaitkan dengan gerakan ekstreem kanan seperti Nazisme dan Fascisme atau dalam Islam gerakan-gerakan fundamentalis di Timur Tengah pasca Revolusi Iran tahun 1979. Atas dasar inilah radikalisme berkembang menjadi konsep radikalisme global. ${ }^{25}$ Untuk gerakan seperti ini pesantren Darul Wahyain sama sekali tidak tidak menampakkan kemiripan.

Jika Anthony Gidden, memiliki tipologi gerakan sosial, dimana gerakan radikalisme keagamaan dapat dikategorikan sebagai transformative movements (gerakan yang bersifat mengubah secara total), yakni gerakan keagamaan yang ingin mengubah tatatan sosial dengan ideology yang mereka yakini dengan cara radikal. Sedangkan gerakan-gerakan keagamaan yang lain dapat masuk dalam tipologi gerakan sosial lain, seperti redemptive movements (gerakan yang bersifat penyelamatan), reformative movements (gerakan yang bersifat pembaharuan) dan alternative movements (gerakan yang bersifat merubah secara parsial). ${ }^{26}$ Melihat tipologi ini nampaknya pesantren Darul Wahyain lebih mengarah pada redemptive movement atau gerakan penyelamatan. Dalam konteks pesantren Darul Wahyain, penyelamatan yang dimaksud adalah penyelamatan umat Islam dari terjadinya krisis ulama yang benar-benar menguasai ilmu agama khususnya Al Qur'an dan Hadis.

Karakteristik utama gerakan radikal di Indonesia pasca orde baru menurut M. Syafii Anwar, sebagaimana dikutip oleh Syamsudin Haris adalah: 1) cenderung mempromosikan peradaban tekstual Islam, sehingga melahirkan sikap kaku, literal, dan tidak toleran terhadap pihak yang berbeda dengan mereka, 2) setia kepada syariab minded, sehingga cenderung memperjuangkan formalisasi syariat Islam, baik pada tingkat negara maupun tingkat kehidupan masyarakat. Akibat formalisasi, maka simbol-simbol keislaman menjadi lebih utama ketimbang substansinya. 3) memiliki kepercayaan berlebihan terhadap teori konspirasi, yakni bahwa kemunduran dan keterbelakangan Islam merupakan konspirasi barat, terutama Amerika dan sekutu-sekutunya. Islam hampir selalu dipandang sebagai korban dari konspirasi kekuatan Yahudi-Kristiani yang dipimpin AS. 4) cenderung

${ }^{24}$ Bilveer Singh, Abdul Munir Mulkhan, Jejaring Radikalisme Islam Indonesia, Jejak Sang Pengantin Bom Bunuh Diri, Yogyakarta: Jogja Bangkit Publisher, 2011, h. 6

${ }^{25}$ Edi Susanto, "Kemungkinan Munculnya Paham Islam Radikal di Pondok Pesantren", Tadrîs. 2 Volume 2. Nomor 1. 2007, h. 3

${ }^{26}$ Antony Giddens, Sociology (Cambridge: Polity Press, 1989), h. 625. 
mengembangkan agenda anti-pluralisme. Ide pluralism dalam bentuk apa pun cenderung dipandang sebagai ancaman bagi kebenaran tunggal yang dimiliki oleh Islam. ${ }^{27}$

Bila melihat karakteristik ini yang terlihat ada kesesuaiannya dengan pesantren Darul Wahyain hanya pada nomor satu dan nomor dua meski tidak sepenuhnya. Karakteristik pertama mempromosikan tekstual Islam bisa diasosiasikan dengan pengembangan budaya tahfizd baik Alqur'an, hadis maupun kitab-kitab lainnya. Di samping nilai positif yang diperoleh dari budaya tahfizd ini, tidak bisa dipungkiri budaya ini membawa pada kondisi psikologis yang kurang kritis karena ada unsur pengabaian terhadap pemahaman (tafhim) dari pesan Al-Qur'an dan Hadis itu sendiri. Dan yang kedua syari'ah minded juga terlihat sesuai juga dengan pesantren ini, dimana syari'ah selain menjadi matakuliah pokok juga ditanamkan seoptimal mungkin menjadi kebiasaan (habit) dalam kehidupan sehari-hari. Melaksanakan Islam secara kaaffah (sempurna) tampak menjadi motto pesantren ini. Yang karena keteguhannya pada pelaksanaan Islam kaffah ini tidak sedikit warga pesantren yang lebih menyukai hidup dalam pesantren ketimbang di dunia luar yang pesantren yang penuh kemaksiatan. ${ }^{28}$

Edi Susanto membuat karakteristik radikalisme agama dengan meramu pandangan Mun'im Sirry, Dekmejian, Yusril Ihza Mahendra dan Muhammad Wahyuni Nafis yang meliputi enam hal, yaitu: 1) cenderung menafsirkan teks-teks kitab suci secara rigid atau kaku dan literalis atau tekstual; 2) cenderung memonopoli kebenaran atas tafsir kitab suci/agama, dan bahkan menganggap dirinya sebagai pemegang otoritas dalam penafsiran agama yang paling absah, sehingga menganggap penafsiran orang atau kelompok lain yang tidak sealiran adalah sesat dan halal untuk dimusuhi. 3) memiliki pandangan yang apriori terhadap ideologi dan budaya barat. Dalam kaitan ini dunia barat dipandang sebagai musuh bebuyutan, imperialis yang selalu mengancam akidah dan eksistensi umat Islam; 4) menyatakan perang terhadap paham dan tindakan sekular; dan 5) cenderung dan tidak segan-segan menggunakan cara-cara kekerasan dalam memperjuangkan nilai-nilai yang diyakininya, khususnya dalam berhadapan dengan modernitas dan sekularitas yang dinilainya menyimpang dan merusak keimanan. ${ }^{29}$

Dengan mempertimbangkan enam karakteristik di atas, pesantren Darul Wahyain secara implisit menepati lima karakteritik pertama namun dengan cara yang implisit dan halus. Sebagai konsekuensi keterkaitan komitmennya terhadap ulama salafus salih, maka sulit dihindari adanya penafsiran agama (Al-Qur'an dan hadis) secara tekstual dan rigid. Demikian pula karena mereka meyakini tafsiran ideal adalah mengikuti ulama salaf, maka paling tidak mereka beranggapan ulama salaflah pemegang otoritas tunggal dalam masalah agama. Apriori terhadap ideologi barat dan memerangi sekularisme sudah pasti karena menjadi tujuan dakwah mereka adalah membentuk masyarakat muslim yang hidup mengikuti cara sebagaimana tiga generasi masyrakat muslim pertama (salaf) dengan segala detail adat dan kebiasaannya. Tampaknya hanya nomor enam yaitu menggunakan cara kekerasan dalam memaperjuangkan nilai-nilai yang diyakini yang sama sekali tidak tampak pada pesanten Darul Wahyain, paling tidak sampai saat ini.

M. Zaki Mubarak, berpandangan tentang karakteristik dari kelompok radikal, terutama kelompok salafi, yaitu: sifatnya cenderung defensif (bertahan pada pendapatnya) saat berdialog/berdebat; defensif atas perubahan-perubahan yang ada hubungannya dengan masalah sosial sekalipun; absolutis dalam memahami konsepsi kebenaran; cenderung literal

\footnotetext{
${ }^{27}$ Syamsudin Haris, Masalah-Masalah Demokrasi dan Kebangsaan Era Reformasi, Jakarta: Yayasan Obor Indonesia, 2014, h. 170

${ }^{28}$ Wawancara dengan Ustadzah pada tanggal 22 September 2017.

${ }^{29}$ Edi Susanto, ibid., h. 4. Karakteristik tersebut disarikan dari beberapa referensi yaitu: Mun'im A. Sirry, Membendung Militansi Agama: Iman dan Politik dalam Masyarakat Modern (Jakarta: Erlangga, 2003), h.2-9; Dekmejian, Islam and Revolution, h. 4-8; Yusril Ihza Mahendra, "Fundamentalisme, Faktor dan Masa Depannya", dalam Muhammad Wahyuni Nafis, ed. Rekonstruksi dan Renungan Religius Islam (Jakarta: Paramadina, 1996), h.100-108.
} 
dalam memahami kitab suci (teks); eksklusif dalam memandang realitas sosial dan tidak percaya pada perubahan sosial (social enginering) dari luar agama Islam; realitas penuh dekadensi dan immoralitas terutama dihubungkan dengan religiusitas sehingga harus ditolak keberadaannya. Oleh sebab itu harus dilakukan perubahan kembali ke arah zaman kemenangan Islam (kemurnian Islam atau purifikasi) yang tidak diarahkan oleh perubahan realitas sosial. ${ }^{30}$ Dengan kata lain, purifikasi atau puritanisme sebetulnya menjadi ideologi paling inti dalam radikalisme. Khaled Abou el Fadl, dalam bukunya The Great Theft, sebagaimana dikutip oleh Zuly Qodir, menyatakan bahwa puritanisme adalah orientasi teologis, bukan mazhab pemikiran yang terstruktur dengan rapi. Oleh sebab itu, orang akan dapat menemukan varian-varian di dalamnya. Tetapi, yang tidak bisa hilang dari puritanisme adalah ideologi supremasi, bahwa mereka selalu merasa lebih unggul dan superior, yang berfungsi sebagai kompensasi atas perasaan kalah, tak berdaya, dan keterasingan, disertai sikap arogansi diri yang di dalamnya terkandung perasaan selalu benar ketika berhadapan dengan yang lain. Sekalipun "yang lain" itu juga tidak mudah diklasifikasikan apakah barat, kaum Ateis, sesama Muslim, pelaku bid'ah atau bahkan kaum perempuan. ${ }^{31}$ Dengan demikian, kelompok radikal yang umumnya memiliki ideologi puritan cenderung otoriter atau merasa paling benar, terlepas perasaan paling benar itu diekspresikan atau tidak.

Poin penting dari pendapat Mubarok di atas adalah pernyataan bahwa puritanisme (kembali ke zaman kemenangan atau kemurnian Islam) merupakan ideologi utama kelompok radikal. Pandangan ini adalah merupakan pandangan yang dianut faham salafi. Sekali lagi di sini tidak dapat dipungkiri keterkaitan faham salafi dan faham radikalisme. Dan kaitan ideologi puritanisme ini dengan Darul Wahyain sulit untuk dipungkiri. Meski mereka menggunakan jalur dan cara damai baik dalam pendidikan maupun dakwahnya, namun idealism dan komitmennya untuk menjadikan masa salaf sebagai model tampak dalam kurikulum, program pendidikan maupun cara mereka hidup.

Dari aspek penampilan sehari-hari, kalangan muslim radikal biasanya tidak jauh beda dengan penampilan muslim di Timur Tengah. Zuly Qodir menjelaskan ciri penampilan kelompok-kelompok gerakan Islam tersebut, di antaranya: memanjangkan jenggot (yang dianggap sebagai bagian dari sunnah Nabi), memanjangkan jilbab, yang sebelumnya pemakaian jilbab hanyalah identik dengan krudung (kerudung Mbak Tutut/Ibu Shinta Abdurrahman Wahid), belakangan berkembang menjadi jilbab panjang. Bagi kelompok jamaah pengajian kampus yang perempuan. Pakaian laki-laki biasanya celana congklang dan baju gamis. Laki-laki juga menghitamkan kening. Dalam bahasa komunikasi biasanya menyebut diri sendiri dengan ana dan antum untuk anda atau kamu. Seringkali digunakan juga panggilan ikhwan (untuk laki-laki) dan akhwat (perempuan), atau akhi dan uk.hti.32

Aspek keseharian muslim sebagaimana yg dikutip dari para penulis di atas adalah sebenarnya ciri atau karakteristik kelompok salafi. Dan tentang cara kehidupan sehari-sehari seperti ini merupakan pemandangan yang lazim terjadi di pesantren Darul Wahyain.

Bila dipotret pesantren Darul Wahyain dengan menggunakan sepuluh karakteristik radikal Islam dari matrik di atas, maka yang tampak meyakinkan hanya nomor satu, enam, tujuh dan sembilan. Karakteristik yang lainnya tidak terungkap dalam penelitian ini. Karakterisik yang sesuai tersebut adalah satu memandang Islam awal sebagai Islam yang ideal yang didukung aksi mengutamakan manhaj salafi dalam kehidupan sehari-hari. Kemudian nomor enam cenderung tekstual dan literal, tampak dalam penafsiran yang kaku dan rigid. Nomor tujuh syariah minded, yang tampak menonjol dalam aksi yang berbentuk memerangi bid'ah dan khurafat. Dan yang ke sembilan mengidealkan budaya Arab, tampak

${ }^{30}$ M. Zaki Mubarak, Genealogi Islam Radikal di Indonesia: Gerakan, Pemikiran dan Prospek Demokrasi, LP3ES, Jakarta, 2007), h. 29.

${ }^{31}$ Zuly Qodir, "Gerakan Salafi Radikal dalam Konteks Islam Indonesia”, ISLAMICA, Vol. 3, No. 1, September 2008, h. 11

${ }^{32}$ Zuly Qodir, ibid., h. 4 
dalam dukungan aksi berupa cara berpakaian ala Arab seperti jalabiyah, niqab, gamis, isbal, memelihara jenggot dan sebagainya. Di samping itu hal ini tampak juga dalam orientasi pendidikan nya yang mengikuti sistem pendidikan Timur Tengah.

\section{Simpulan}

Berdasarkan penjelasan pada bab-bab sebelumnya, maka dapat disimpulkan bahwa keberadaan Pondok Pesantren Darul Wahyain di Magetan tidak memenuhi kriteria untuk disebut sebagai pesantren radikal. Argumnetasi yang bisa penulis kemukakan di sini, adalah:

1. Terkait dengan kriteria suatu pesantren dapat dikategorikan sebagai pesantren radikal sudah dirumuskan oleh para pakar sebagai berikut: 1) cenderung menafsirkan teks-teks kitab suci secara rigid atau kaku dan literalis atau tekstual; 2) cenderung memonopoli kebenaran atas tafsir kitab suci/agama, dan bahkan menganggap dirinya sebagai pemegang otoritas dalam penafsiran agama yang paling absah, sehingga menganggap penafsir kitab orang atau kelompok lain yang tidak sealiran adalah sesat dan halal untuk dimusuhi. 3) memiliki pandangan yang apriori terhadap ideologi dan budaya barat. Dalam kaitan ini dunia barat dipandang sebagai musuh bebuyutan, imperialis yang selalu mengancam akidah dan eksistensi umat Islam; 4) menyatakan perang terhadap paham dan tindakan sekular; dan 5) cenderung dan tidak segan-segan menggunakan cara-cara kekerasan dalam memperjuangkan nilai-nilai yang diyakininya, khususnya dalam berhadapan dengan modernitas dan sekularitas yang dinilainya menyimpang dan merusak keimanan.

2. Terkait dengan kurikulum Pesantren Darul Wahyain Magetan dapat dijelaskan di sini bahwa secara umum, kurikulum yang diterapkan di Pesantren Darul Wahyain dibedakan berdasarkan program/level. Ada 3 level/program yang terdapat di pesantren yaitu: program I'dadiyah, Ta'biliyah, dan Ta'miliyah. Untuk program idadiyah, materi yang diajarkan adalah adab (akhlak/etika), tajwid, dan bahasa Arab.

3. Terkait dengan keberadaan Pesantren Darul Wahyain Magetan sendiri bisa dinyatakan bahwa tidak ada kategori tersebut padanya. Dengan mempertimbangkan beberapa penjelasan sebelumnya secara umum Pesantren Darul Wahyain tidak sepenuhnya sesuai. Meskipun melalui gerakan pendidikan dan dakwahnya, mereka mencita-citakan sebuah kehidupan sosial keagamaan yang ideal sebagimana yang terjadi pada zaman ulama salaf. Namun mereka menempuh cara damai dan evolutif tidak sebagaimana perubahan yang dilakukan oleh gerakan radikal.

\section{Daftar Pustaka}

Ahmad Darmadji, "Pondok Pesantren dan Deradikalisasi Islam di Indonesia", Millah,Volume XI, No 1, Agustus 2011.

Antony Giddens, Sociology, Cambridge: Polity Press, 1989.

Ayub Mursalin dan Ibnu Katsir, "Pola Pendidikan Keagamaan Pesantren dan Radikalisme: Studi Kasus Pesantren-pesantren di Provinsi Jambi",Kontekstualita, Vol. 25, No. 2, 2010.

Bilveer Singh, Abdul Munir Mulkhan, Jejaring Radikalisme Islam Indonesia, Jejak Sang Pengantin Bom Bunuh Diri, Yogyakarta: Jogja Bangkit Publisher, 2011.

Din Wahid, "Nurturing Salafi manhaj: A study of Salafi pesantren in contemporary Indonesia", Wacana, Vol. 15 No. 22014

Edi Susanto, "Kemungkinan Munculnya Paham Islam Radikal di Pondok Pesantren", Tadrîs. 2 Volume 2. Nomor 1. 2007

Jamhari dan Jajang Jahroni, Gerakan Salafi Radikal di Indonesia , Jakarta: PPIM, 2004.

Martin van Bruinessen, "Genealogies of Islamic Radicalism in Post-Suharto Indonesia", South East Asia Research, Vol. 10, No. 2, 2002. 
Muhammad Najib Azca, "Yang Muda Yang Radikal: Refleksi Sosiologis Terhadap Fenomena Radikalisme Kaum Muda Islam di Indonesia Pasca Orde Baru", Pidato Dies Natalis Fisipol UGM disampaikan pada 5 Desember 2012 di Fisipol UGM.

Muhammad Wildan, "Mapping Radical Islam: A Study of Proliferation of Radical Islam in Solo, Central Java" dalam Martin van Bruinessen, Contemporary Development in Indonesian Islam: Explaining the Conservative Turn, Yogyakarta: Institute of Southeast Asian Studies, 2013.

M. Imam Zamroni, "Islam, Pesantren, dan Terorisme", Jurnal Pendidikan Agama Islam, Vol. II, No. 2, 2005, hlm. 177-194.

Mohammad Kosim, "Pesantren dan Wacana Radikalisme", Karsa, Vol. IX, No. 1 April 2006, hlm. 843-853.

Martin van Bruinessen, Contemporary Development in Indonesian Islam: Explaining the Conservative Turn ,Yogyakarta: Institute of Southeast Asian Studies, 2013.

Mun'im A. Sirry, Membendung Militansi Agama: Iman dan Politik dalam Masyarakat Modern, Jakarta: Erlangga, 2003.

M. Zaki Mubarak, Genealogi Islam Radikal di Indonesia: Gerakan, Pemikiran dan Prospek Demokrasi, LP3ES, Jakarta, 2007.

Nurcholish Madjid, Bilik-bilik Pesantren: Sebuab Potret Perjalanan, Jakarta: Paramadina, 1997.

Sindu Galba, Pesantren sebagai Wadah Komunikasi, Jakarta: PT. Rineka Cipta, 2004.

Sukamto, Kepemimpinan Kyai dalam Pesantren, Jakarta: LP3ES, 1999.

Syamsudin Haris, Masalah-Masalah Demokrasi dan Kebangsaan Era Reformasi, Jakarta: Yayasan Obor Indonesia, 2014, hlm. 170

Yusril Ihza Mahendra, "Fundamentalisme, Faktor dan Masa Depannya", dalam Muhammad Wahyuni Nafis, ed. Rekonstruksi dan Renungan Religius Islam, Jakarta: Paramadina, 1996.

Zamakhsyari Dhofier, Tradisi Pesantren: Studi tentang Pandangan Hidup Kyai, Jakarta: LP3ES, 1994.

Zuly Qodir, "Gerakan Salafi Radikal dalam Konteks Islam Indonesia”, ISLAMICA, Vol. 3, No. 1, September 2008, hlm. 11

ttps://kumparan.com/nur-khafifah/ciri-ciri-orang-terjangkit-paham-radikal-menurut-bnpt\# C7DuMlsrtju5M631.99

https://kbbi.web.id/radikalisme

https://darulwahyain.wordpress.com/metode-mulazamah/. Diakses pada 15 Oktober 2017.

http://www.subliyanto.id/2015/01/mengenal-konsep-mulazamah.html. Diakses pada 20 Oktober 2017.

Berdasarkan keterangan Arsyaad Mbai di https://www.merdeka.com/peristiwa/ini-16kelompok-radikal-indonesia-yang-dibaiat-pemimpin-isis.html diakses 11 Oktober 2017

Kementerian Agama, "Keputusan Menteri Agama Republik Indonesia Nomor 284 Tahun 2001 tentang Ma'had Aly, Pasal 1 dan 3.

Pejelasan tentang metode mulazamah juga dapat dilihat dalam video Profil Pesantren Darul Wahyain di kanal https://www.youtube.com/watch?v=_9urI6Kz4WI. Diakses pada 1 November 2017.

Wawancara dengan Ustad Rasyid Ridlo Ba'asyir, pada 21 September 2017. Pernyataan ini juga dibenarkan, misalnya oleh Ustadz Hanif dan Ustadzah Iffa, ustadz dan ustadzah Pesantren Darul Wahyain.

Wawancara dengan ustadzah Iffa, pada 22 September 2017.

Wawancara dengan Ustadz Hanif, pada 21 September 2017. Deskripsi tentang seluruh program Pesantren Darul Wahyain diambil dari dokumen tertulis Pesantren Darul wahyain (tidak dipublikasikan).

Wawancara dengan Lukman, pada 22 September 2017.

Wawancara dengan santri putra: Abdul Aziz, Lukman, dan Fahruz Razi, pada 22 September 2017. 
Wawancara dengan Nafiah, santri putri (santriwati), pada 22 September 2011. 